\title{
The Impact of Suicide Attacks on Voting Behavior: The Case of November 2015 Early Elections
}

\author{
İntihar Saldırılarının Seçmen Davranışına Etkisi: Kasım 2015 Erken Seçim Örneği
}

Ceren YEGEN ${ }^{*}$

\begin{abstract}
Terror aims to disrupt peace and security of countries. Suicide attack is a form of terrorism is carried out in many parts of the world today. These attacks aiming at destroying countries and citizens, and targeting civilians or state institutions, have been the current agenda in Turkey with cases such as Suruc Attack and Ankara Railway Station Attack following the June 7, 2015, elections and the Syrian Civil War. These attacks, which deeply affect the citizens and harm the country, can also have an impact on political behaviors such as social practices. Individuals, as voters, may vote under the influence of political and social events. In this study, effects of suicide attacks in Turkey on voting behavior were demonstrated by means of a reception analysis on the example of the Ankara Train Station Attack (October 10, 2015). In this regard, this study analyzes the effects of suicide attacks in Turkey on voting behavior for the November 1, 2015, early elections by carrying out an ethnographic research methodology. As the conclusion of the study, the individuals were observed to be aware of the fact that the real purpose of terrorism was to scare and harm. The participants supported the government in case of the suicide attacks and other terrorist attacks. The majority of the participants believed that the suicide attack, which took place in the train station intersection in Ankara, would have no effect on the behaviors of the voters for the Early Elections of November 1, 2015.
\end{abstract}

Keywords: Turkey, Terror, Suicide Attack, Elections, Voting Behavior

\section{$\ddot{\mathbf{O z}}$}

Terör, ülkelerin huzur ve düzenini bozmayı, sarsmayı amaçlar. Terörün bir biçimi olan intihar saldırıları bugün dünyanın birçok yerinde gerçekleştirilmektedir. Ülkelere ve yurttaşlarına zarar vermeyi amaçlayan ve yurttaşları ya da devlet kurumlarını hedef alan bu saldırılar, Türkiye'de 7 Haziran 2015 Seçimi’nden ve Suriye İç Savaşı’ndan sonra, Suruç Saldırısı ve Ankara Garı Saldırısı gibi olaylar ile gündeme oturmuştur. Yurttaşları derinden etkileyen ve ülkeye zarar veren ilgili saldırılar, toplumsal

* $\quad$ Asst. Prof. Dr., Muş Alparslan University, Faculty of Communication, Muş, Turkey, c.yegen@alparslan.edu.tr. 
pratikler gibi siyasal davranışlara da etki edebilmektedir. Çünkü birer seçmen de olan bireyler oy verme pratiklerini siyasi ve toplumsal olayların etkisinde gerçekleştirebilmektedir. Bu çalışmada, Türkiye’de gerçekleşen intihar saldırılarının seçmen davranışına etkisi, 10 Ekim 2015 Ankara Garı Saldırısı örneklemine yönelik gerçekleştirilen bir alımlama analizi ile ortaya konmuştur. Böylelikle, Türkiye’de gerçekleşen intihar saldırılarının 1 Kasım 2015 Erken Seçimi bağlamında seçmen davranışına nasıl yansıdığı analiz edilmiştir. Çalışmada etnografik yöntem kullanılmıştır. Çalışmanın sonucunda, bireylerin terörün asıl amacının korkutmak, zarar vermek olduğunun farkında oldukları görülmüştür. Katılımcıların intihar saldırıları ve terör bağlamında hükümete desteği söz konusudur. Katılımcıların çoğunun kanaati, Ankara’da tren garı kavşağında gerçekleşen intihar saldırısının 1 Kasım 2015 Erken Seçimi’ndeki oy verme davranışlarına etki etmeyeceği yönündedir.

Anahtar Kelimeler: Türkiye, Terör, İntihar Saldırısı, Seçim, Seçmen Davranışı

\section{Introduction}

With the September 11 and the subsequent attacks in many parts of Europe (the United States, France, Belgium, etc. $)^{1}$, most people agreed that terrorism was a global problem. Today, terror is spreading fear through suicide attacks carried out especially by ISIL (Islamic State of Iraq and the Levant). ISIL, which Ahmet Kasim Han described as an "apocalyptic" formation, convinces its terrorists that the end of the world has come, therefore they have to wage jihad to go to heaven. It is carrying out terrorist actions abusing Islam. This terror in global scale has affected capital circulation and tourism today, since tourists are afraid of going to countries where suicide attacks take place and terrorist actions are common ("Paris'te terör: 127", 2015). According to Dolunay Şenol, Sezgin Erdem and Elif Erdem (2016), the terrorist organization known as ISIL has succeeded in expanding its sphere of influence in a short period of time by using the advantages of globalization and has become a threat to the world, rather than a regional one (p. 277). ISIL announced the initiation of "A Soldier's Harvest" campaign designed to intimidate/liquidate/ assassinate Iraqi security forces and to establish control over territory in July 2013 (Barrett, 2014, p. 6). ISIL also uses social media extensively. The organization aims to increase its target audience by sharing 90,000 tweets every day, bringing terror propaganda to a new kind popularized by using new media environments. At the core of ISIL's narrative, there are familiar themes for the most Muslims. In the middle of 2014, ISIL declared that its main purpose was to expand the Caliphate (Schmid, 2015). About 30,000 fighters from at least 85 countries joined the ISIL as of December 2015 (Benmelech \& Klor, 2016). ISIL brings religion and violence side-by-side and characterizes a global threat especially with suicide attacks in many places.

Many suicide attacks occurred in Turkey as well. Suicide attacks, the figure of which showed an increase after June 7, 2015 General Elections and since the start of the Syrian Civil War, resulted in the death of many citizens. For example, at a meeting held in Ankara with the

1 For example, the ISIL militant attacked a supermarket in France while in Belgium, 3 people were killed in a clash between ISIL militants and security forces (“Belçika’daki terör saldırısını", 2018; “Fransa’da rehine krizi”, 2018). 
participation of Revolutionary Trade Unions Federation (DİSK), Turkish Medical Association, Peoples' Democratic Party (HDP) and many other civil society organizations on October 10, 2015, two explosions occurred and many people died ("Ankara'da barış mitingine", 2015). The terrorist attacks in 2015 were mostly claimed by the ISIL and the PKK (Kurdistan Workers' Party) terrorist organizations, and these attacks affected both the voter behavior and everyday practices of the citizens. Therefore, this study aimed to analyze the effect of suicide attacks in Turkey on voters' behaviors.

For this purpose, a reception analysis particular to the November 1, 2015 early elections was applied to 10 respondents selected by simple random technique in Ankara by using ethnographic method. The analysis conducted between October 20-27, 2015 is both important and necessary for understanding the effect of suicide attacks on voting behavior in Turkey. By discussing the concept of terror and suicide attacks in its theoretical aspect and which is limited to Ankara example on November 1, 2015 early elections, this study will also contribute to the field of political science by focusing on voter behavior as well as to researches on political communication.

\section{Terror}

The terror, which can be characterized as a "war" and against which conscious militaristic and psychological defense are necessary, is a universal problem and needs propaganda to legitimize itself while being fed from violence (Keen, 2006; Arndt \& Vess, 2008). The terrorist organizations and terrorism, aim at frequent coverage in the media with their actions in order to acquire legitimacy (Kellner, 2003, pp. 86-87). Terrorism which cannot be easily defined is claimed to be a phenomenon designed to draw attention to specific goals and events (Lizardo, 2008, p. 91; Hoffman, 2010, p. 615).

Terror, which Kışlalı (1991) defines as a Latin-origin word meaning "big fear" or "trembling from fear", means "political violence" or "intimidation" with the meaning of terrorism, and it has ideological, religious, and cultural influences. For example, in Ireland, during the 1990s, terrorism was considered synonymous with Catholicism (pp. 18-20). Along with this, allegations were also put forward that the Islamophobia increased in many parts of the world following the September 11 (9/11) attack in the United States in 2001. The September 11, which, according to Nilfer Göle (2008), was "an attack to the heart of Western hegemony", pointed to a new beginning in globalization (p. 13). According to Brodeur (2015), on the other hand, the impacts of terrorism on contemporary society have been one of the most controversial issues since September 11, 2001. Therefore, it is important to identify the economic consequences of terrorist attacks and to better understand the channels through which terrorism affects local economies (Brodeur, 2015). Terrorism can be addressed as a strategy and relationship process as well (Tilly, 2005, p. 11).

Today, terrorism, which uses the power of developing communication technologies, conducts propaganda activities as a dynamic phenomenon through the internet. Terrorist organizations, which make promotions through internet sites and mention about their actions (sharing images and photos, publishing videos of their actions, etc.) also aim at collecting sympathizers. 
According to Weimann (2004), terrorist internet sites mainly target three groups: current and potential supporters, international public, and enemy societies (p. 9-15). This situation also describes the digital propaganda activities of the terrorist organizations because individuals are now mostly on social media and social media is an important public area. According to Theohary and Rollins (2011), today "the Internet is used by international insurgents, jihadists, and terrorist organizations as a tool for radicalization and recruitment, a method of propaganda distribution, a means of communication, and ground for training" (p. 2).

As in many places, the propaganda of any terrorist organization is subject to certain punishment in Turkey as well. Anti-Terror Law adopted in 1991 in Turkey regulates related crimes (Anti-Terror Law, 1991). In the fight against the terrorists, taking measurements that will remove the opportunities for terrorists to take action on certain targets will take away the initiative to take action (Cantenar \& Tümlü, 2016, p. 17). However, it is also necessary to think deeply about the motives (social, cultural, etc.) behind participation in terrorist organizations (Jacques \& Taylor, 2013).

\section{Terror and Suicide Attacks}

As Miryam Lindberg (2010) says, "terrorism is a polemical word that has long provoked interpretation discrepancies in the international community" (p. 1). Suicide attacks can also be interpreted as a shape of terrorism. Suicide attacks target countries, citizens, or government agencies, and aim to harm by performing terrorist acts. Suicide attacks in many parts of the world cause great damage and loss for various purposes and nowadays are performed by ISIL after alQaeda. According to some approaches, al-Qaeda and ISIL have developed different paths and targets despite the similar origins (Toledo Gomes \& Mikhael, 2018, p. 1). With its suicide attacks in many places in Turkey and throughout the world, ISIL embarked on a so-called Islamic jihad and attempted to ground its attacks on Islam. According to Pape (2003), terrorist organizations have increasingly begun to rely on suicide bombings to reach their grand political objectives (p. 343).

Terrorism by suicide attacks is an international problem that puts the prosperity of the entire population at risk. According to standard disclosures, religious fanaticism is the primary driving force in the production of suicide bombers. Religion, especially Islam, is claimed to have a minimal direct role in the production of suicide bombers (Kassim, 2008). It is also another widespread claim that suicide attacks by radical religious groups target "rich democracies" (Berman \& Laitin, 2005). According to Pape (2003), the main reason why Islam is referred with terror is the indication of Islamic fundamentalism as the main cause of many attacks, including those on September 11,2001. However, the assumptions about the connection between suicide terrorism and Islamic fundamentalism are misleading (p. 343). Committing suicide is prohibited in Islam, but Islamic terrorist organizations somehow convince their suicide bombers that they would go to heaven and that they are actually serving Allah and the Prophet (Munir, 2008, p. 79). Moreover, most suicide bombers are trained in religious schools (Sela-Shayovitz, 2007, p. 162). Suicide attacks can be performed not only with religious interests but also with nationalist 
sentiments and national interests. For example, the suicide attacks of Japanese kamikazes may be devoted to the benefit of the Japanese nation, or it can be attributed to devotion to the family teachings (Orbell \& Morikawa, 2011).

According to researchers, there has been much progress in the research of suicide bombers in the last decade (Açıkgöz, 2016: 321). Competent authorities are trying to revive a psychopathological approach to understand the causes of this trend. It is obvious that terror is a multidimensional phenomenon. It is very clear, however, that it is largely necessary to focus on the political and social origins of suicide bombing, as suicide terrorism is rising all over the world, and there is a great confusion about its potential causes (Brym \& Araj, 2012, p. 439; Kerner, 2006; Pape, 2005).

\section{Suicide Attacks Around the World and in Turkey}

Jeffrey William Lewis (2013) claims that the current suicide attack trend started in Lebanon at the beginning of the 1980s (p. 2). Such attacks were also observed in countries such as Turkey and Chechnya. The most intensified suicide bombings in Chechnya occurred in the summer of 2000 following the Chechen constitutional referendum, when Chechen separatists used trucks full of explosives to attack military targets in Chechnya. Suicide attacks increased after the 9/11. According to the index figures, the number of fatalities has steadily grown over the last 14 years, from 3,361 in 2000, to 11,133 in 2012 and 17,958 in 2013 (MacAskill, 2014).

According to Global Terrorism Index 2015, deaths from terrorism have increased dramatically over the last 15 years. The number of people who have died from terrorist activity has increased ninefold since 2000 (Institute for Economics \& Peace, 2015, p. 14).

FIGURE 1 DEATHS FROM TERRORISM, 2000-2014

Deaths from terrorism have increased dramatically over the last 15 years. The number of people who have died

from terrorist activity has increased ninefold since the year 2000

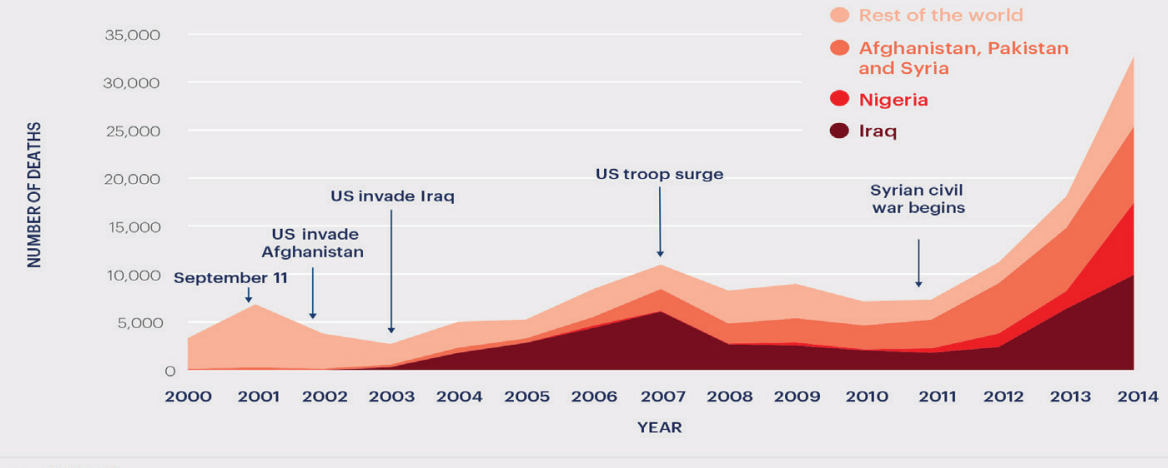

Source: START GTD

Figure I. Deaths From Terrorism 2000-2014. Reprinted from Global Terrorism Index 2015 (p. 14), by Institute for Economics \& Peace, 2015. 
According to Global Terrorism Index 2017, there is a global decline in the number of deaths from terrorist attacks to 25,673 people, which is a $22 \%$ improvement from the peak in 2014. Terrorism has fallen significantly in the epicentres of Syria, Pakistan, Afghanistan and Nigeria, which are four of the five countries most affected by terrorism (Institute for Economics \& Peace, 2017, p. 2).

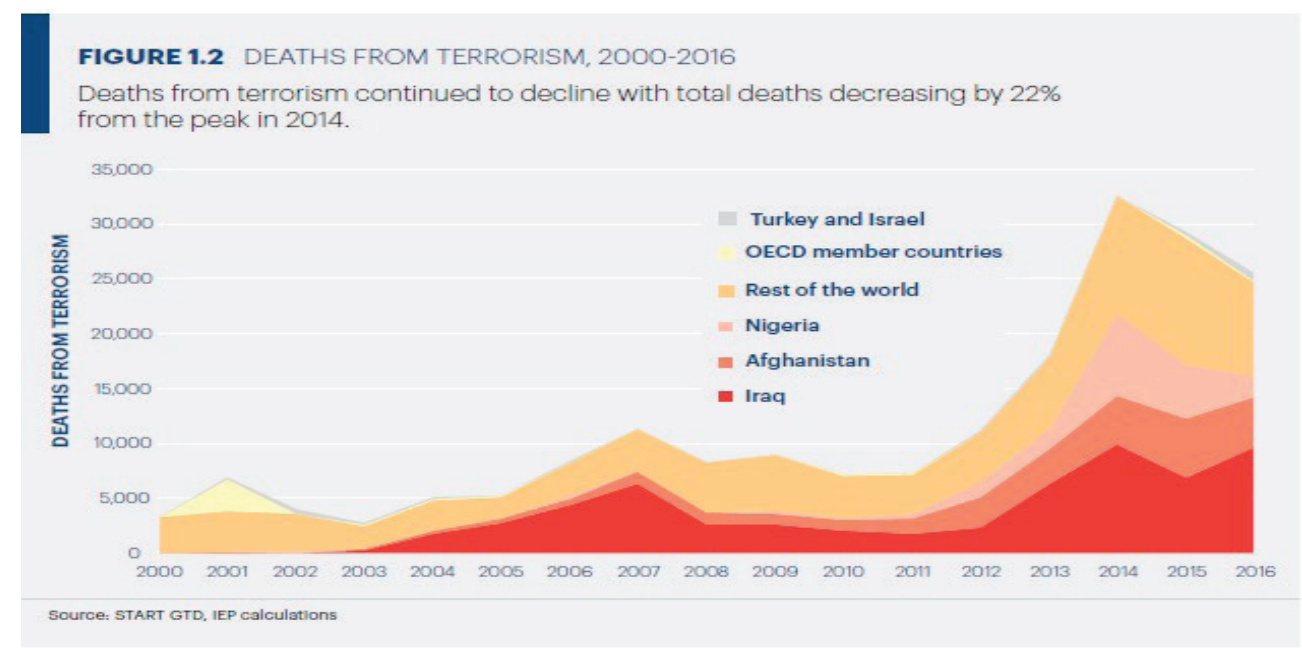

Figure 2. Deaths from Terrorism 2000-2016. Reprinted from Global Terrorism Index 2017 (p. 15), by Institute for Economics \& Peace, 2015.

Since the 2000s, the number and the geographical range of suicide attacks have expanded and attacks reached extraordinary levels in the Iraq War. Suicide attacks also became widespread in Afghanistan, and the Taliban increasingly turned to suicide attacks. Suicide bombers are one of the most extreme criminological problems that the international community has encountered in modern times, and terrorists use suicide bombers as a low-cost, low-tech, and low-risk weapon. Suicide bombers are found ready, they demand less training, leave no traces, and spread fear to the society. From past to present, besides men, women have also been used as suicide bombers (Crenshaw, 2007, p. 134; Horowitz, 2015; Mujaddidi, 2013, p. 1; Zedalis, 2004; Yom \& Saleh, 2004; Kurz \& Bartles, 2007, pp. 531-533).

The USA launched a global war on terror after September 2001, which was followed by President George W. Bush who declared a global war on terror 12 hours after 9/11 attacks. It took time for the USA to understand how to fight against an enemy motivated by a radical revolutionary religious ideology. Bush, his supporters, and leading Democrats proposed different policies, and the common point of these policies was the effective use of force against terrorism. The Democrats thought that the principal move that would bring success to the Bush administration would be to make smarter diplomacy and intensify cooperation with key alliances. According to approaches, Bush's war on terrorism created more terrorists and this will may continue as long 
as the US does not radically change its policies on terrorism (Gordon, 2007, p. 53). In addition, policymakers of the United States should not underestimate the policies of counterterrorism in any country and should observe whether there is a reduction in transnational terrorism or not (Dobrot, 2007, p. v; Horowitz, 2015, p. 70; Milanovic, 2007, p. 375; Piazza, 2008, p. 469). The war against terrorism is a common goal for many states today (Elden, 2009).

Suicide attacks in Turkey started in the 1990s and generally targeted civilians, military personnel, police officers, security officers, and politicians. Many people lost their lives in suicide bomb attacks in Turkey, and these attacks aimed at destroying the peace of the country, and they deeply affected the society. While speaking of suicide attacks, it is also necessary to mention the assassinations (bomb attacks, shoot somebody dead, etc.) and examples of such tragic events which have been experienced in Turkey. For example, journalists Uğur Mumcu and Çetin Emeç, and scientists such as Ahmet Taner Kışlalı and Bahriye Üçok were targeted by various terrorist groups and were assasinated due to their writings or ideas. Suicide attacks are still a problem today. Accordingly, one of these attacks, the October 10, 2015, Ankara Railway Station attack was selected as the case study for this research.

\section{Elections and Voting Behavior in Turkey}

There is an enthusiastic and passive mood of the masses of the people (Petrov, 2007, p. 58). This mood is very important for political systems. While the elections are the most important part of democratic systems, the voters, which is another important element, are equally important. In the absence of voters, democracy is not mentioned (Yegen, 2018, p. 8). As Winrich Kühne (2010) points out, elections have a great role in the context of democracy (p. 1). In the determination of elections systems, the principles like justice in representation and benefit in management have great importance (Tuncer, 2003).

Elections are very important in democratic societies and have a long history. The elections (general elections), where the citizens vote to elect the people to rule themselves, also have a long history in Turkey. Local elections even have a longer past than the general elections (Alkan, 2006). As Öztekin states, debates on the concepts of election and political representation, which started in the 14th and 15th centuries in European countries, began in the Ottoman Empire in the late 19th century, and in 1876, the parliamentary system was accepted (As cited in Erkmen, 2018, p. 1225). In 1923, Turkey was established as a republic and entered a new period. For many years, Turkey (Republic of Turkey) has been ruled by a single party-government. In 1946, the country has adopted a multi-party system (Erkmen, 2018, p. 1226). It is also important to note that the election campaigns (especially contemporary election campaigns with its elements) which have undergone major transformations in the last few decades, have great importance (Grbeša, 2005, p. 88).

In elections, the students not only act as voters but also have the opportunity to have an effect on determining their future, their nation, and their country. Voting behavior is one's using his/her right in such a determination. While there are several factors influencing voting behavior, there are also several approaches intending to understand these factors. 
In sociological preference approach, individuals are deemed to be strictly loyal to the group, party or to the views of the party they belong to. According to this approach, a vote used in an election is the reflection of their political identity on their political preferences. The voter votes in every election accordingly. On the contrary, the psychological preference approach claims that voting behavior comes out of the psychological bond of love one has established with a party outside his/her own group. Though the individuals may vote for another party for any reason, they will vote for their ex-party again in the following election. The rational preference approach, on the other hand, claims that one thinks about his/her material interests only, when voting. It assumes that the individual is aware of his/her own interests and gives the decisions that will ensure, improve or protect such interests (Gül, Cansever \& Turhan, 2015, p. 238).

There are numerous factors affecting voting behaviors and decisions. Cultural, social and political factors can play a role in voting behavior. While these factors may naturally come out, they may also be created on purpose in order to influence the preferences of voters. Knowing the factors affecting voting preferences of the individuals is guiding the parties to shape their policies and election campaigns (Karagöl \& Dama, 2015). All the factors influencing the political behaviors are claimed to have a direct effect on politics and thus, on political preferences (Beren, 2013, p. 194).

Political election campaigns are important for shaping and guiding voting behavior. The basic target of political election campaigns is to enhance the relationship with the voters and to increase the number of votes for the candidates. According to Çinko (2006), economic conditions, rather than ideological preferences, are determinant in voting behaviors in Turkey (pp. 114-115). In other words, it is really difficult to categorize people in Turkey according to their ideological preferences.

The number of studies about the factors affecting voting behavior in Turkey can be said to have increased recently. On the other hand, the number of studies about the voting behaviors of young voters, are claimed to be rather insufficient (Çavuşoğlu \& Pekkaya, 2016, p. 19). It would be wise to review the previous literature studies about voting behavior and social, political, economic and cultural factors etc. affecting this behavior, in terms of local and general elections.

In this respect, the conclusions reached by Hasan Güllüpunar, Ersin Diker and Emre S. Aslan (2013) in their study entitled "An Experimental Research on Candidate-Based Voting Preference in Terms of Voting Behaviors", are significant. This study asserts that the interests of the country is the primary factor affecting voting behaviors whereas the party constitutes the second most important, which indicates a voter's loyalty towards a political party. On the other hand, party loyalty can also be suggested to be shaped by rational preferences. The high ratio of the interests of the country, which can be considered to have a rational basis, the high ratio of party-based voting and the low ratio of ideology can be interpreted to mean that, party loyalty has a rational basis.

Resul Öztürk's analysis (2017) revealed educational and income-based differences between voting behaviors and demographic features. In the study of Beren (2013) entitled "The Factors Affecting the Voting Behavior and Election Safety: The Case of Sanliurfa", it is claimed that the 
demographic, feudal, cultural and safety-related factors are obviously more dominant in Sanliurfa, unlike the findings of research studies carried out in other cities. It is important to reconsider the demographic, feudal, cultural and safety-related factors in order for the locals to determine their political preferences by their free will (p. 211).

The findings of a research study on the students of Bulent Ecevit University (BEU) are also important in understanding the political behaviors of young voters. According to the study, there are numerous factors affecting the political behaviors of the students in local elections. In local elections, BEU students focused more on the experience, projects, rationality of the promises of the candidates than the origin of the candidates, which can indicate the path for improvement in the future electoral competitions (Çavuşoğlu \& Pekkaya, 2016, p. 33).

The study of Erkan T. Demirel, Ahmet Yatkın, Muhammet Düşükcan, Neslihan Derin, Arzu Çakınberk and Mehmet Güven (2013) entitled "Establishing Voters Loyalty in Local Politics through Municipal Service Quality: The Case of TRB-I Region" dealt with voting behavior and the factors affecting this behavior, in terms of local elections. According to the research, the perceptions of voters about the quality of municipal services and the leadership qualities of the mayors and the level of voter's loyalty toward the mayor may be affected by demographic variables such as gender, age, marital status, educational background, level of income, occupation as well as the political identities and the party to be voted for (p. 332). The study of Erdoğan Teyyare and Mehmet Avc1 (2016) entitled "Voting Behaviors in Local Elections: The Case of Zonguldak in 2014 Elections" also focused on the voting behavior in local elections. The study aimed at revealing the factors affecting the voting behavior in 2014 local elections in Zonguldak city, within the framework of theoretical approaches. According to the findings, voting behavior mainly comes out within the scope of rational preferences. In this respect, the political background, projects and past actions of the candidate can be stated to be affecting the preferences of the voters.

The study of Nermin Unat-Abadan et al. (2014) entitled "Voting Behaviors of the Turkish People Living in Europe and the 2014 Election of the Presidency of the Republic of Turkey", is significant as it discusses the 2014 Elections of the Presidency by focusing on the voters living abroad. According to the study, while there were great expectations for the elections from the voters abroad particularly the European-Turkish people in Germany, the level of participation failed to meet the expectations compared to the participation in Turkey.The study concludes that the problem of insufficient participation can be partially solved with a better-organized election process and by ensuring that the voters abroad are also represented in the general elections (pp. 33-34).

As is seen, there are numerous factors affecting voting behavior, which are mainly social, cultural or economic. This is because the voter is a political, social and cultural body. On the other hand, avoiding voting behavior can also be a reaction to the disorganized structure of the election process.

The field studies focused on the significant opinions of the young voters as much as the adults,. It would be wise to point here the necessity to increase the number of studies intending 
to assess and understand voting behavior, which has been shaped in parallel with the new media tools. Today, new media tools have a political mission and they form an important base for propaganda activities. New media tools are particularly important as a fast and ergonomic channel in reaching to the young voters.

The political behavior of the rapidly changing Turkish society is multifaceted, and various sensitivities can play a role in the direction of political behavior. Social transformations, such as rapidly advancing democracy in the last 20 years, have a direct impact on citizens' voting behavior in Turkey. Like rising conservatism, nationalism is also a major political and cultural orientation in the country (Çarkoğlu and Kalaycıoğlu, 2009, pp. 75-76; Erişen, 2013).

According to Caner Taslaman (2011), in Turkey, Islam is undergoing a rapid transformation and increasing its power. Normalization and democratization of politics in Turkey has followed a bumpy road (p. 180-181). While restrictions on political rights and freedoms and freedom of association continue to pose a significant obstacle to democratization, the European Union (EU) anchors in taking steps towards further democracy (Keyman, Erdem \& Ağırdır, 2013, p. 7). Nevertheless, in the cases of national sensitivity, Turkish society is docking and moving away from political or ideological polarization. Civil society, an important element such as democracy and a self-constitutional structure, depends on the state and the society (Saribay, 1997, pp. 32-33).

\section{An Analysis on Voting Behavior and the Impact of Suicide Attacks}

\section{Method and Data Collection}

The method used in the analysis part of the work is the ethnographic method. Frequently used in reception surveys, the ethnographic method refers to the researcher's observations by living in different cultures (Şeker, 2009). The researcher spends time with the focus group, whose views and behaviors are the subjects of the research observation. In reception analysis, media messages are the discourses that are coded culturally for the general public. The audience is the means of meaning production. Reception studies constitute an important place in communication studies. Researchers, who put the audiences into an active position, think that they use television in the direction of their own needs and desires. Researchers around the tradition of cultural studies move from the idea that the audience can interpret television messages in different ways (Aydın, 2007, p. 119; Yücel, 2014, p. 8; Schrøder, 2016; MacGregor \& Morrison, 1995; Schmitz, Piedras \& Wottrich, 2015). In Stuart Hall's analysis of the reception it is seen that the uses and gratification approach is utilized (Şeker, 2009).

Therefore, in this study, a reception analysis was applied to 10 voters (participants) selected by the simple random technique, who were living in Ankara. The participants were asked about their opinions on the suicide bombing that took place in the Railway Station intersection in Ankara on October 10, 2015, and it was particularly investigated how the attack influenced voters' behavior in the November 1, 2015 early elections. 


\section{Scope and Limitation}

This method was chosen by the author to obtain detailed information from the participants. In addition, the number of participants does not represent Turkish voters in terms of quantity, which can be evaluated as a limitation for the study. A total of 10 participants were interviewed in order to obtain limited but detailed data. Two media organisations were also included in the sample.

\section{Features of the Participants}

Participants are of different age, education, gender, and socio-economic groups consisting of five men, five women whose ages vary between 20 and 45. Participants are students (3), housewives (3), doctors, academics, civil servants and private security officers, and their education levels are between high school and post-graduate education. Monthly incomes of the participants are between TL 1,200 and TL 12,000.

Table I. Participants and Occupations

\begin{tabular}{|l|l|}
\hline Occupation & Number \\
\hline Academics & 1 \\
\hline Civil Servants & 1 \\
\hline Doctors & 1 \\
\hline Housewives & 3 \\
\hline Private Security Officers & 1 \\
\hline Students & 3 \\
\hline
\end{tabular}

The research also benefited from Tülay Şeker's (2009) reception analysis. For the analysis carried out between October 20,2015, and October 27, 2015, the experiences, daily practices, and political tendencies of the voters were observed. The analysis was conducted before the election to understand the voter behavior towards the November 1, 2015, early election. For 15 minutes, participants were shown and read two news reports that were published in www.hurriyet.com.tr and www.sabah.com.tr on October 10, 2015, related to the Ankara Railway Station Intersection Attack, which were chosen as representatives of the centrist press. ${ }^{2}$

Participants also watched the videos in the related news. Adding videos and images to the news is an important function and contribution of the new media. Participants watched these videos from the author's personal laptop. The selection of the two news sites aimed at obtaining comparable data on the approach of the two media outlets about the suicide bombing. In addition

2 The news that were shown, read and published on www.hurriyet.com.tr on 10.10.2015 is as follows: "Explosion at Railway Station Intersection in Ankara", Access URL: http://www.hurriyet.com.tr/ankara-tren-gari-kavsagindapatlama-30278748, "Explosion in Ankara is in world press", Access URL: http://www.hurriyet.com.tr/ankaradakipatlama-dunya-basininda-30279110.

The news that were published on www.sabah.com.tr on 10.10.2015 is as follows: "Terrorist attack in Ankara: There are casualties and injured", Access URL: http://www.sabah.com.tr/gundem/2015/10/10/ankarada-teror-saldirisiolu-ve-yaralilar-var, "Explosion in Ankara", Access URL: http://www.sabah.com.tr/galeri/turkiye/ankarada-patlama. 
to this, it is thought that reviewing the online news sites such as www.hurriyet.com and www. sabah.com.tr about the related event will also contribute to the work in the new media field. Because it is thought that the new media has become more popular, especially for young people, than traditional media and there are a number of studies carried out focusing on internet journalism other than traditional reporting. ${ }^{3}$

After the news presentation, in-depth interviews with the participants were made and the obtained data were textualized by the qualitative method. Before the presentation of the news and interview, a questionnaire was created in line with the information in the news to understand the participants' reception and remembering of the news content. Participants were asked to explain how they learned the event, and the reception and remembering of the incident were investigated through the most important information and the most impressive image left in their minds. Participants were also asked how often they followed www.hurriyet.com and www.sabah.com. tr. They were asked about their points of view regarding the suicide attacks and suicide bombers, and particularly, the one happened in the Ankara Railway Station intersection. Participants were also asked about the government's policies about these attacks, what they thought about the relevant attacks and how that attack would affect their voting behaviors on the November 1 , 2015, early elections.

\section{Research Questions}

The research questions to be examined with the data obtained from the interviews created within the scope of the study are as follows:

- Do individuals realize that terrorism's main purpose is to intimidate/scare?

- How can people support the government to prevent or fight terrorism?

- Does terrorism affect voting behavior?

- What are the main phenomenon that affect voting behavior?

- Will the Suicide Attack at the Railway Station Intersection in Ankara affect the voting behavior of the November $1^{\text {st }}$ elections?

- What do the attendants attribute the suicide attacks to?

- Which news source do the attendees gravitate to when there is an extraordinary case?

- How did www.hurriyet.com and www.sabah.com deliver news about the related attack?

\section{November I, 20 I 5, Early Election and Impact of Suicide Attacks on Voter Behavior over the Ankara Case}

Two explosions took place in Labor, Peace and Democracy Meetings held by the participation of DISK, KESK, Turkish Medical Association, HDP, and many non-governmental organizations 
on October 10, 2015, in Ankara at the Railway Station intersection, many civilians lost their lives, and many civilians were injured. It was determined that the attacks were carried out by Yunus Emre Alagoz and Omer Deniz Dundar who were in connection with ISIL ("Bombacilar belirlendi", 2015).

As a result of the general elections on June 7,2015, the AK Party lost the power, the coalition came to the agenda, but after the coalition negotiations failed, November 1, 2015 early elections took place. In order to understand the impact of suicide attacks in Turkey on the voter behavior, a reception analysis was conducted for the electoral behavior in the November 1, 2015 early elections over the Ankara Railway Station attack.

It would be meaningful to look at a case (Suicide Attack at the Railway Station Intersection in Ankara) in which national sensitivities can be observed in the political behavior of Turkish voters.

\section{In-depth Interviews with the Participants:}

News Content of www.hurriyet.com.tr and www.sabah.com.tr about the Suicide Attack at the

\section{Railway Station Intersection in Ankara}

According to the participants, the content of the news stories posted on the both news sites are "where and when the explosion took place", "how many people died and how many were injured", "which organization they thought was responsible", "during which event the explosion took place", "who were present during this activity", "what they thought about the fact that the explosion took place before the election", "foreign press' interest and reactions", "the panic of the citizens at the scene" and "expectation of explanation from the authorities". According to the participants" statements, "videos" and "photographs" were used in the presentation of the news.

\section{How Often the Participants Followed www.hurriyet.com.tr and www.sabah.com.tr}

Among the participants, three stated that they followed www.hurriyet.com.tr regularly and one followed www.sabah.com.tr. Six of the participants stated that they do not follow both sites regularly.

\section{How the Participants Learned about the Incident}

"I heard that it was a peace meeting. I heard from TV that an explosion took place in the meeting. In the footage served first, people were in fear. Blood was everywhere. “

"My friend shared on Facebook that there was an explosion in Ankara. I turned on the TV, and most of the channels were showing the "explosion in Ankara" as the breaking news. I watched what was happening on television and cursed it, guessing it was a terrorist attack. “

"I was in Kizllay with my friends when the incident happened. We heard that there was an explosion in Ankara from the conversations of the young people sitting at the table near us. 
Someone was showing something from his phone to his friends. We wondered and learned the details from an internet site. There were horrible images..."

"I learned from the news that there was an explosion. My wife said 'it was a pity' and explained the details; she said it was a peace meeting, it was like a feast". According to the reports, there were many casualties and injuries. “

"I learned about the incident when I entered Twitter. People tweeted that there was an explosion in Ankara during a meeting around the railway station. Information and images were being shared from the explosion site. Some were talking about a relative who attended that meeting and some mentioned ISIL as the usual suspect."

"While I was at work, friends told me about an explosion in Ankara. The explosion was at a meeting attended by many civil society organizations and there were too many people there. I immediately searched for the event on the internet. All the news sites mentioned about the explosion but there were not any details since the incident had just taken place. I learned about the reason behind the explosion later."

"I learned about the incident after I saw that the people I followed cursed terror on Twitter. I thought 'Oh no! A terrorist attack again!' I learned the details from the tweets on the incident. These were mostly photos and videos from the scene. There were some people lying on the ground and others wailing. Obviously, the number of casualties and injuries was too high. “

"I was in the kitchen. A news channel was on TV and my husband was saying something angrily. He turned up the volume of the TV. I asked 'what happened', my husband said 'I think a suicide bombing took place in Ankara'. I wondered and came to the living room to watch the news. The anchorman was talking about an explosion at the meeting."

"My shift had just finished and I was exhausted. I checked my Facebook account. When I entered my account through the application on my phone, I saw that my friends shared news and images about an explosion. I learned about the incident in this way. Then I checked the details from a news site. "

"I was doing something at work. A workmate came and said "Have you heard about the news of the explosion at the meeting held in Ankara. There were a lot of people..! He showed me the images shared on Facebook and I felt so sorry. Then I entered the application and website of a media organ on my own phone and learned what happened."

\section{The Most Important Information \& Most Impressive Image in the Minds of the Participants}

"People covered in blood lying on the ground"

"People in blood, flags on the ground, pain"

"People who wail for the people lying on the ground" 
"The pain and horror on the faces of people"

"A young girl examining the wounded list"

"A wounded person carried probably on a flag or a pennant"

"People who help people lying on the ground and frozen bloody bodies"

"Innocent people"

“Terror..!”

"People in turmoil"

\section{Participants' Views on Suicide Attacks}

"It's nothing but cruelty."

"Because of these attacks, Turkey has become like a Middle East country where there is always violence."

"I think these attacks increased with ISIL."

"How the brains of the people, who do these attacks are washed? The mind boggles."

"The enemies of Turkey decided to stir up trouble when they saw that Turkey was progressing. I am sure foreign forces are behind this.”

"I think it is meaningful that this happened just before the elections."

"We can't go to crowded places anymore. Miscreants! They both frighten and take life."

"I guess all the enemies of Turkey came together."

"ISIL and the PKK need to be destroyed. The great Republic of Turkey destroyed many of them, it will destroy them too."

"They are trying to pull Turkey into the Middle East quagmire, and while doing so, they are using the citizens of this country. What is the logic of being a suicide bomber?"

\section{Participants' Views on Suicide Bombers}

"I think suicide bombers are brain-washed and incapable people!"

"They are people who have definitely lost the control of their mind."

"In which mood they perform such a thing, it's cruel and definitely not understandable!"

"I believe a suicide bomber is no different from a serial murderer!"

"They certainly aim at mass bloodshed, what kind of a cruelty is this?"

"I think these people are selected among people who have nothing to lose and they are brainwashed." 
"Cruel terrorists."

"They must be the most remorseless people in the World! They are brain-washed and under control."

"Vulgar people! I really feel sorry for their families."

\section{Participants' Views on Government's Policies on These Attacks}

"The government is fighting against the ISIL and the PKK with ambition, but a more effective fight is needed and both organizations must be destroyed."

"They said solution process, and here are the results..! Suicide bombers come to Turkey freely and they blow themselves. Then we learn that they are trained in different places. Citizens get hurt because of these!"

"Suicide attacks have increased and we are afraid. I think there is intelligence weakness. The government should investigate thoroughly."

"A war should be declared against the PKK and ISIS. We have had enough with all these explosions, attacks, martyrs..! “

"The government seems to be alone in its fight against terrorism. The opposition should give its support to the government in this matter. I think especially the attitude of HDP will be very important. "

"The government is doing its best. What else can it do? Where is the opposition? "

"The government has embarked on a war against terror, but HDP should also keep its distance between the terrorist organization (PKK) and itself as expected/desired. Because they are a political party in the parliament of the same state/country and they receive salaries from this state and they represent the citizens of this country."

"I think the solution process should never have been started."

"I find the government successful in its fight against terrorism. I think this should be the only agenda of the government. "

"I think the government's approach to the events in Syria led to this attack. I think we should never have been involved in that quagmire. We learned about ISIL with the incidents that took place in Syria. “

\section{What the Suicide Attack That Took Place at the Railway Station Intersection in Ankara} Made People Think

"The first thing that came to my mind was that the explosion was a suicide attack."

"I hoped that there would be no casualties and injuries, but ..." 
"I thought that they wanted to give a political message. I thought it was only one explosion, then I learned that two people had blown themselves, and I said,damn you all'. I said to myself 'Look what our beautiful country has become...”'

"Obviously it was the work of ISIL or the PKK. I think the aim was to create turmoil in the country and make people think that there is a security-intelligence weakness in the country."

"I thought about the people who went there. I was very upset. I wondered about the details and wanted to learn them as soon as possible."

"I thought about all the people who lost their lives. Who knows what kind of people they were. They left their loved ones behind. And their dreams..."

"As a mother, the first thought that came to my mind was the mothers who lost their children there. It hurt me so much, damn terrorism."

"I could think nothing but hope that there would not be too many casualties. I lost all my joy."

"I was scared. I thought it was necessary to stay away from crowded places and warned my children."

\section{The Impact that the Suicide Attack That Took Place at the Railway Station Intersection} in Ankara Will Have on the Voting Behavior during November 1, 2015, Early Elections

"I will support the government in its war on terror. I am going to vote for them."

"I am going to protest the elections and not vote."

“This attack will not affect my vote."

“Attacks will not affect my vote."

"I am sure I will go to the ballot box fearing that there might be an explosion or an attack somewhere."

"For me, voting means contributing to the future of the country. I will vote, but I do not want to say for which party. But these incidents will not affect my decision."

"My voting will not be affected by this attack, but how the country has become!"

"I will not vote."

"I do not think my vote will be about this attack."

"I will not be able to vote because I have not transferred my residence to the city where I moved. I have not done anything to be able to vote anyway. “

\section{Findings and Conclusion}

Suicide attacks as a form of terrorism can be seen in several places in the world. The attacks, which are mainly carried out for political reasons, aim at mass injuries and disruption of the 
peace and safety in countries. The citizens are deeply affected by such attacks. The attacks not only cause sorrow but also make the citizens question the safety of the country. This is why the suicide attack is a socio-psychological matter as well as a political issue, and it poses a global threat. The suicide attack that took place at the railway station intersection in Ankara also affected the Turkish citizens deeply. Many people lost their lives and many were left in profound sadness.

Within the scope of this study, it was observed in the analysis of the reception made with the participants from various demographic characteristics that individuals are aware of the fact that the main aim of terrorism is to terrorize and harm; in this regard, an effective war against the PKK and the ISIL should be launched.

Research questions were also answered within the scope of the study. Most of the participants support the government in this regard. Participants condemn terrorism and are saddened by the lost lives and their families. Most of the participants believe that the suicide attack that took place at the railway station intersection in Ankara will not affect their voting behavior during the Early Elections of November 1, 2015. Some participants stated that they would not vote. However, the increase in suicide attacks is partly attributed to the solution process and partly to the Syrian Civil War.

The majority of the participants believe that suicide attackers are brain-washed people. To most of them, what a suicide attacker does is wild and cruel. It would be wise to note here that, it is certainly impossible to exactly understand the moods and behaviors of suicide attackers. The things we know about them are limited to what is written in literature. Most of the participants learned the related suicide attack from television and social media. Some of the participants used the internet as the news source. It was seen in the scope of the study that although participants did not generally use www.hurriyet.com and www.sabah.com.tr, they apply to the internet news sites as a news source.

The most impressive image left in the minds of the participants was the citizens lying in blood on the ground. These images were also discussed in the media in the context of ethics. According to the participants, www.sabah.com.tr used more visuals about the incident. However, both sites shared the related news under "Last Minute News." This practice shows that the media is sensitive to and responsible for social incidents.

It should be noted that conditions affecting voting behavior in Turkey as well as in many countries and societies are mostly in cultural, political and social aspects. In Turkey, terror cannot scare and browbeat the individuals, because people engage more with the national awareness and support for such attacks. In such cases, the media's attitudes and practices are also very important. 


\section{References}

Açıkgöz, R. (2016). İntihar saldırıları ve terörizm ilişkisi üzerine eleştirel bir değerlendirme (Filistin örneği). Mukaddime, 7(2), 321-340.

Alkan, O. M. (2006). Türkiye’de seçim sistemi tercihinin misyon boyutu ve demokratik gelişime etkileri. Anayasa Yargısı (23), pp. 133-165.

Ankara'da barış mitingine bombalı saldırı: 95 ölü. (2015). BBC. Retrieved from https://www.bbc.com/ turkce/haberler/2015/10/151010_ankara_saldiri_genel.

Anti-Terror Law (Republic of Turkey). (1991). Law Number: 3713, Acceptance Date: 12/4/1991 Published Official Newspaper: Date: 12/4/1991 No: 20843.

Arndt, J., \& Vess, M. (2008). Tales from existential oceans: Terror management theory and how the awareness of our mortality affects us all. Social and Personality Psychology Compass, 2(2), pp. 909-928.

Aydın, S. O. (2007). Alımlama araştırmaları ve kültürel çalışmalar geleneğinin katkısı. İstanbul Ticaret Univesity Journal of Social Sciences, 6(11), pp. 119-131.

Barrett, R. (2014). The Islamic State. The Soufan Group. Retrieved from http://soufangroup.com/wpcontent/uploads/2014/10/TSG-The-Islamic-State-Nov14.pdf

Belçika'daki terör saldırısını IŞiD üstlendi. (2018, May 30). Cumhuriyet. Retrieved from http://www. cumhuriyet.com.tr/haber/dunya/986494/Belcika_daki_teror_saldirisini_ISiD_ustlendi.html.

Benmelech, E., \& Klor, E. F. (2016). What explains the flow of foreign fighters to ISIS? National Bureau of Economic Research. Retrieved from http://www.nber.org/papers/w22190.pdf

Beren, F. (2013). Seçmen tercihine etki eden faktörler ve seçim güvenliği: Şanlıurfa ili örneği. Journal of Academic Inquiries, 8(1), pp. 191-214.

Berman, E., \& Laitin, D. D. (2005). Hard targets: Theory and evidence on suicide attacks. National Bureau of Economic Research. Retrieved from http://www.nber.org/papers/w11740.pdf.

Bombacilar belirlendi. (2015, October 14). Cumhuriyet. Retrieved from http://www.cumhuriyet.com.tr/ haber/turkiye/387751/Bombacilar_belirlendi.html.

Bradshaw, P., \& Rohumaa, L. (2013). The online journalism handbook: Skills to survive and thrive in the digital age. London: Routledge.

Brodeur, A. (2015). Terrorism and employment: Evidence from successful and failed terror attacks. Bonn: The Institute for the Study of Labor (IZA).

Brym, J. R., \& Araj, B. (2012). Are suicide bombers suicidal? Studies in Conflict \& Terrorism, 35(6), pp. 432443.

Cantenar, O. F., \& Tümlü, F. (2016). PKK terör örgütünün eylemlerinin güvenlik güçleri zayiatı açısından analizi. Science Journal of Turkish Military Academy, 26(1), pp. 1-22.

Çarkoğlu, A., \& Kalaycığlu, E. (2009). The rising tide of conservatism in Turkey. New York, NY: Palgrave Macmillan.

Çavuşoğlu, H. \& Pekkaya, M. (2016). Yerel seçimlerde genç seçmenlerin siyasal davranışlarına ilişkin bir inceleme: Bülent Ecevit Üniversitesi örneği. Uluslararası Yönetim, İktisat ve İsletme Dergisi, 12(29), pp. 17-40.

Paris’te terör: 127 ölü. (2015). CNN Türk. Broadcast dated 11.14.2015.

Çinko, L. (2006). Seçmen davranışları ile ekonomik performans arasındaki ilişkilerin teorik temelleri ve Türkiye üzerine genel bir değerlendirme. Ankara University SBF Dergisi, 61(1), pp. 103-116.

Crenshaw, M. (2007). Explaining suicide terrorism: A review essay. Security Studies, 16(1), pp. 133-162. 
Demirel, T. E., Yatkın, A., Düşükcan, M., Derin, N., Çakınberk, A., \& Güven, M. (2013). Yerel siyasette seçmen bağlılığını belediye hizmet kalitesi aracılığıyla oluşturmak: TRB - I bölgesi örneği. The Journal of Academic Social Science Studies, 6(4), pp. 305-336.

Dobrot, A. L. (2007). The global war on terrorism: A religious war? Carlisle, PA: Strategic Studies Institute. Retrieved from https://ssi.armywarcollege.edu/pdffiles/PUB822.pdf.

Elden, S. (2009). Terror and territory: The spatial extent of sovereignty. Minneapolis \& London: University of Minnesota Press.

Erişen, C. (2013). The political psychology of Turkish political behavior: Introduction by the special issue editor. Turkish Studies, 14(1), pp. 1-12.

Erkmen, A. (2018). Türkiye'de 1950 ile 2002 yılları arasında uygulanan genel seçim sistemlerinin halk iradesine etkisi. Gaziantep University Journal of Social Sciences, 18(3), pp. 1225-1247.

Fransa'da rehine krizi! IŞiD’li terörist süpermarket bastı. (2018). Sözcü. Retrieved from https://www.sozcu. com.tr/2018/dunya/fransada-rehine-krizi-isidli-terorist-supermarket-basti-2306289/.

Institute for Economics \& Peace. (2015). Global Terrorism Index 2015. http://economicsandpeace.org/wpcontent/uploads/2015/11/Global-Terrorism-Index-2015.pdf.

Institute for Economics \& Peace. (2017). Global Terrorism Index 2017. Retrieved from https://reliefweb.int/ sites/reliefweb.int/files/resources/Global\%20Terrorism\%20Index\%202017\%20\%284\%29.pdf.

Göle, N. (2008). İç içe girişler: İslam ve Avrupa. İstanbul: Metis Yayınları.

Gordon, H. P. (2007). Winning the right war: The path to security for America and the world. New York, NY: Times Books.

Grbeša, M. (2005). To what extent and in what ways do election campaigns matter? Politička misao, XLII(5), pp. 87-95.

Gül, H., Cansever, N., \& Turhan, M. (2015). 2011 genel ve 2014 yerel seçimlerinde Isparta'da seçmen davranışı analizi. Toplum ve Demokrasi, 9(19-20), pp. 225-241.

Güllüpunar, H., Diker, E., \& Aslan, S. E. (2013). Oy verme yaklaşımları bağlamında aday merkezli seçmen tercihi üzerine deneysel bir araştırma. Akademik Bakış, (35), pp. 1-21.

Hoffman, M. A. (2010). Voice and silence: Why groups take credit for acts of terror. Journal of Peace Research, 47(5), pp. 615-626.

Horowitz. C. M. (2015). The rise and spread of suicide bombing, Annual Review of Political Science, 18, pp. 69-84.

Jacques, K., \& Taylor, P. J. (2013). Myths and realities of female-perpetrated terrorism. Law and Human Behavior, 37(1), pp. 35-44.

Karagöl, T. E., \& Dama, N. (2015). Partilerin vaatleri seçim sonuçlarını nasıl etkiler? Seta Perspektif. Retrieved from http://file.setav.org/Files/Pdf/20150521154027_partilerin-vaatleri-secim-sonuclarini-nasiletkiler-pdf.pdf.

Kassim, H. S. (2008). The role of religion in the generation of suicide bombers. Brief Treatment and Crisis Intervention, 8(2), pp. 204-208.

Kellner, D. (2003). September 11, spectacles of terror, and media manipulation: A critique of jihadist and Bush media politics. Logos, 2(1), pp. 86-102.

Keen, D. (2006). War without end: Magic, propaganda and the hidden functions of counter-terror. Journal of International Development, 18(1), pp. 87-104.

Kerner, H. J., Coester, M., \& Bott, K. (2006). How to deal with terrorist threats? Major problems and handling opportunities for local authorities. Report from the 4th local seminar in Tübingen, 27-28 November 2006. Retrieved from https://efus.eu/files/fileadmin/efus/pdf/CAT_Tuebingen.pdf. 
Keyman, F., Erdem, T., \& Ağırdır, B. (2013). Türkiye’nin demokratikleşmesi için kapsamlı bir siyasi parti ve seçim sistemi reformu önerisi. İstanbul: İstanbul Politikalar Merkezi. Retrieved from http://ipc. sabanciuniv.edu/wp-content/uploads/2013/12/a.pdf.

Kışlalı, A. T. (1991). Siyasal sistemler siyasal uzlaşma ve çatışma. Ankara: İmge Kitabevi Yayınları.

Kühne, W. (2010). The role of elections in emerging democracies and post-conflict countries: Key issues, lessons learned and dilemmas. Berlin: Friedrich-Ebert-Stiftung, International Policy Analysis. Retrieved from http://library.fes.de/pdf-files/iez/07416.pdf.

Kurz, W. R. and Bartles, K. C. (2007). Chechen suicide bombers. Journal of Slavic Military Studies, 20(4), pp. 529-547.

Lewis, J. W. (2013). The human use of human beings: A brief history of suicide bombing. Origins, 6(7). Retrieved from http://origins.osu.edu/article/human-use-human-beings-brief-history-suicidebombing.

Lindberg, M. (2010, February 20). Understanding terrorism in the twenty-first century. Grupo de Estudios Estratégicos GEES. Retrieved from http://www.gees.org/files/article/20022010093237_ Analisis-07561.pdf.

Lizardo, O. (2008). Defining and theorizing terrorism: A global actor-centered approach. Journal of WorldSystems Research, XIV(2), pp. 91-118.

MacAskill, E. (2014). Fivefold increase in terrorism fatalities since 9/11, says report. The Guardian. Retrieved from https://www.theguardian.com/uk-news/2014/nov/18/fivefold-increase-terrorism-fatalitiesglobal-index.

MacGregor, B., \& Morrison, E. D. (1995). From focus groups to editing groups: a new method of reception analysis. Media, Culture \& Society, 17, pp. 141-150.

Milanovic, M. (2007). Lessons for human rights and humanitarian law in the war on terror: Comparing Hamdan and the Israeli targeted killings case. International Review of the Red Cross, 89(866), pp. 373-393.

Mujaddidi, F. G. (2013). Suicide attacks in Afghanistan: Why now? (Unpublished master's thesis). The Graduate College at the University of Nebraska, Lincoln, Nebraska. Retrieved from http:// digitalcommons.unl.edu/cgi/viewcontent.cgi?article=1025\&context=poliscitheses.

Munir, M. (2008). Suicide attacks and Islamic law. International Review of the Red Cross, 90(869), pp. 71-89.

Orbell, J., \& Morikawa, T. (2011). An evolutionary account of suicide attacks: The Kamikaze case. Political Psychology, 32(2), pp. 297-322.

Öztürk, R. (2017). Siyasal pazarlamanın seçmen davranışlarına etkisinde ağızdan ağıza iletişimin aracılık rolü: Konya ili örneği (Unpublished doctoral dissertation). Nevşehir Hacı Bektaş Veli University, Institute of Social Sciences, Nevşehir.

Pape, A. R. (2003). The strategic logic of suicide terrorism. American Political Science Review, 97(3), pp. 343-361.

Pape, A. R. (2005). Dying to win: The strategic logic of suicide terrorism. New York, NY: Random House.

Petrov, G. (2007). Beyaz zambaklar ülkesinde. İstanbul: Koridor Yayınları.

Piazza, A. J. (2008). Incubators of terror: Do failed and failing states promote transnational terrorism? International Studies Quarterly, 52(3), pp. 469-488.

Sarıbay, A. Y. (1997). Türkiye’de demokrasi ve sivil toplum. Liberal Düşünce, (6), pp. 32-43.

Schmid, P. A. (2015). Challenging the narrative of the "Islamic State". The Hague: The International Centre for Counter-Terrorism (ICCT). Retrieved from https://icct.nl/wp-content/uploads/2015/06/ICCTSchmid-Challenging-the-Narrative-of-the-Islamic-State-June2015.pdf. 
Schmitz, D., Piedras, E., \& Wottrich, L. (2015). Reception studies: State of the issue and challenges ahead. Intercom: Revista Brasileira de Ciências da Comunicação, 38(1), pp. 109-127.

Schrøder, C. K. (2016). Reception analysis. In G. Mazzoleni, K. G. Barnhurst, K. Ikeda, R. C. M. Maia \& H. Wessler (Eds.), The International Encyclopedia of Political Communication. Chichester: Wiley.

Sela-Shayovitz, R. (2007). Suicide bombers in Israel: Their motivations, characteristics, and prior activity in terrorist organizations. International Journal of Conflict and Violence, 1(2), pp. 160-168.

Siapera, E., \& Veglis, A (Eds.). (2012). The handbook of global online journalism. Oxford: Wiley-Blackwell.

Şeker, T. (2009). 5N1K haber programının alımlama analizi. Selçuk İletişim, 5(4), pp. 105-117.

Şenol, D., Erdem, S., \& Erdem, E. (2016). IŞİD: Küresel bir terör örgütü. The Journal of International Social Sciences, 26(2), pp. 277-292.

Talabi, O. F. (2011). The internet and journalism practice in Nigeria. Global Journal of Human Social Science, 11(10), pp. 15-20.

Taslaman, C. (2011). Küreselleşme sürecinde Türkiye’de İslam. İstanbul: İstanbul Yayınevi.

Teyyare, E., \& Avc1, M. (2016). Yerel seçimlerde seçmen davranışları: 2014 yerel seçimleri ve Zonguldak ili örneği. Siyaset, Ekonomi ve Yönetim Araştırmaları, 4(1), pp. 51-76.

Theohary, C. A., \& Rollins, J. (2011). Terrorist use of the internet: Information operations in cyberspace. CRS Report for Congress, Prepared for Members and Committees of Congress. Retrieved from https://fas.org/sgp/crs/terror/R41674.pdf.

Tilly, C. (2005). Terror as strategy and relational process. International Journal of Comparative Sociology, 46(1-2), pp. 11-32.

de Toledo Gomes, A., \& Mikhael, M. M. (2018). Terror or rerrorism? Al-Qaeda and the Islamic State in comparative perspective. Brazilian Political Science Review, 12(1). Retrieved from http://www.scielo. br/pdf/bpsr/v12n1/1981-3821-bpsr-12-1-e0002.pdf.

Tuncer, E. (2003). Osmanlidan günümüze seçimler (1877-2002). Ankara: TESAV.

Unat-Abadan, N., Çıdam, V., Çınar, D., Kadirbeyoğlu, Z., Kaynak, S., Özay, B., \& Taş, S. (2014). Avrupa’da yaşayan Türklerin oy verme davranışları ve 2014 Türkiye cumhurbaşkanlığı seçimi. Boğaziçi University \& Friedrich Ebert Stuffing. Retrieved from http://www.fes-tuerkei.org/media/pdf/ einzelpublikationen/Voting_final_tuerk.pdf.

Yegen, B. (2018). Türkiye'de ve seçilmiş ülkelerde politik bütçe döngülerinin karşılaştırmalı olarak değerlendirilmesi (1996-2015) (Unpublished doctoral dissertation). Pamukkale University Institute of Social Sciences Department of Finance, Denizli.

Yom, S., \& Saleh, B. (2004). Palestinian suicide bombers: A statistical analysis. Retrieved from http://www. epsusa.org/publications/newsletter/2004/nov2004/saleh.pdf.

Yücel, A. (2014). “Muhteşem Yüzyıl” dizisinin alımlama analizi: Kadın ve erkek imajı üzerine farklı okumalar. E-Journal of Hacettepe University Sociological Studies. Retrieved from http://www.sdergi.hacettepe. edu.tr/makaleler/muhtesemyuzyil.pdf.

Zedalis, D. D. (2004). Female suicide bombers. Carlisle, PA: Strategic Studies Institute. Retrieved from https://ssi.armywarcollege.edu/pdffiles/PUB408.pdf.

Weimann, G. (2004). Www.terror.net: How modern terrorism uses the internet. Washington, DC: United States Institute of Peace (pp.1-12). Retrieved from www.usip.org/pubs/specialreports/sr116.pdf. 